\title{
Synthesis, Characterization and Catalytic Activity of Iron Pillared Clays.
}

\author{
J. Biomorgi*, J, M. J. Pérez Zurita*, C. Scott*, C. Urbina de Navarro**.
}

(*) Centro de Catálisis y Petroquímica. Universidad Central de Venezuela, DC. 1040.

(**)Centro de Microscopía Electrónica. Universidad Central de Venezuela. Caracas, DC. 1040.

The energy consumption in the world is increased in a significant way with passing of the time. The environmental demands in the developed nations are every time but severe as for the pollutant content in generating energy compounds, particularly, fuels. That has resulted in a high number of researchers studying new catalytic materials that satisfy this conditions. There are many inorganic solids with regular structures that incorporate spaces having molecular dimensions. Sheet silicates, often called clays, are cations exchangers.

The spaces between the layers are accesible even to large molecules. The intercalation of cations produce pillared clays. Clay minerals are generally aluminosilicates forming sheets. They have a negative charge and they stay united through electrostatic interactions by means of cations located among the sheets. Formation of pillared clays consists on substituting clays cations (metals of the group I and II) for iron (in oxide form) The pillared clays have shown an interesting catalytic activity in diverse reactions [1].

In this work it was possible to optimize the synthesis of these solids, using the ultrasound, as well as to evaluate the catalytic activity of solids in hydrotreatments reactions. The pillared clays were characterized by BET, XRD and Electron Microscopy [2].

In Table 1 are shown the superficial area of the obtained pillared clays, it can be observed how this parameter increases in comparison with the natural clay, as for the clay synthesized by the conventional method as for the solids synthesized by the ultrasound technique, being the superficial area for 20 minutes of synthesis. In a same way the results of XRD reported in the Table 1 indicate that there was expansion among the layers of the synthesized clay by both methods, having a maximum of layer lattice distance. These results seem to indicate that 20 minutes is the best time of synthesis for ultrasound method.

The optimum time of synthesis of the pillared clays by the conventional method is obtained for an ionic exchange of 180 minutes and using suspensions to $1 \%$ clay/water [2]. Using 180 minute of synthesis and 50\% clay/water suspensions, pillared clays were also obtained, finding a good structural properties in the obtained solids, as for superficial area and basal spacing (Table 1). The ultrasound pillared clay (20 minutes and 50\% clay/water) did not have good thermal stability.

In figure 1 the pillared clay is shown (20 minutes and 20\% clay/water) being able to measure the basal spacing of the same ones (Table 1). For pillared clay 20 minutes and $50 \%$ clay/water, it was not possible to distinguish the structure, instead of that it was observed a dispersed iron phase, figure 2. That fact could be responsible for the drop in thermal stability of this solid. 
This work suggests that the use of the ultrasound is a very valuable tool in the synthesis of pillared clays because it is possible to obtain solids with good textural and structural properties, diminishing the time of synthesis up to $90 \%$ and using concentrated suspensions.

\section{References}

[1] R. E. Grimm. "Clay Mineralogy”, Mc. Graw Hill, (1986).

[2] J. Biomorgi, Undergraduate Thesis, Universidad Central de Venezuela. Caracas. 2000.

Tabla 1. Superficial Area and Basal Distance

\begin{tabular}{|c|c|c|c|c|}
\hline Clay & $\begin{array}{c}\% \\
\text { Clay } / \mathrm{H}_{2} \mathrm{O}\end{array}$ & $\begin{array}{c}\text { Superficial } \\
\text { Area }\left(\mathrm{m}^{2} / \mathrm{g}\right)\end{array}$ & $\begin{array}{c}\text { Basal } \\
\text { Distance }(\AA) \\
(\mathrm{XRD})\end{array}$ & $\begin{array}{c}\text { Basal } \\
\text { Distance }(\AA) \\
(\mathrm{TEM})\end{array}$ \\
\hline Natural Clay & --- & 33 & 13 & ---- \\
\hline Pillared Clay (C) & 1 & 196 & 20 & 18,5 \\
\hline $\begin{array}{l}\text { Pillared Clay (U) } \\
\text { (10 minutes) }\end{array}$ & 1 & 128 & 18 & ----- \\
\hline $\begin{array}{l}\text { Pillared Clay (U) } \\
\quad(15 \text { minutes) }\end{array}$ & 1 & 140 & 19 & ----- \\
\hline $\begin{array}{l}\text { Pillared Clay (U) } \\
\text { (20 minutos) }\end{array}$ & 1 & 195 & 19 & 18 \\
\hline $\begin{array}{l}\text { Pillared Clay (U) } \\
\text { (25 minutos) }\end{array}$ & 1 & 131 & 18 & -- \\
\hline $\begin{array}{l}\text { Pillared Clay (U) } \\
\text { (20 minutes) }\end{array}$ & 50 & 183 & 19 & ----- \\
\hline
\end{tabular}

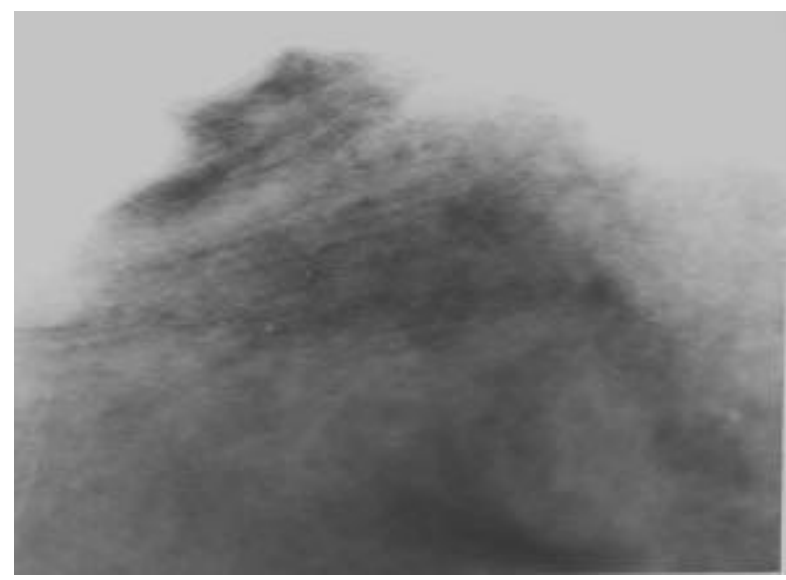

$200 \AA$

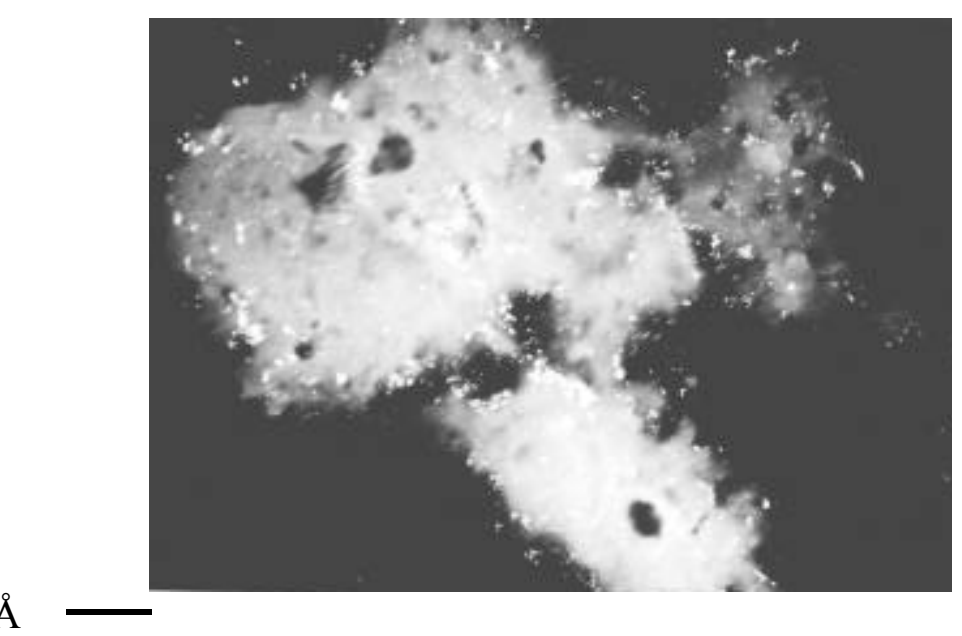

Figure 2. Dark field. Ultrasound pillared clay. $50 \%$ Clay $/ \mathrm{H}_{2} 0$. Figure 1. Ultras
$1 \%$ Clay $/ \mathrm{H}_{2} 0$. 